Volume 10, Nomor 2, November 2018, pp 223-230 Copyright (C) 2017 Jurnal Akuntansi Maranatha, Program Studi Akuntansi, Fakultas Ekonomi,

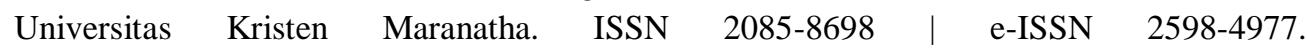
http://journal.maranatha.edu

\title{
Analisis Penilaian Kinerja Organisasi Perangkat Daerah di Kota Bandung
}

\author{
Meyliana \\ Fakultas Ekonomi Program Studi Akuntansi Universitas Kristen Maranatha \\ (Jalan Prof. drg. Suria Sumantri No.65 Bandung) \\ meyliana_oey@yahoo.com \\ Lidya Agustina \\ Fakultas Ekonomi Program Studi Akuntansi Universitas Kristen Maranatha \\ (Jalan Prof. drg. Suria Sumantri No.65 Bandung) \\ lidya_kho@yahoo.com

\section{Chandra Setiawan} \\ Fakultas Ekonomi Program Studi Akuntansi Universitas Kristen Maranatha \\ (Jalan Prof. drg. Suria Sumantri No.65 Bandung)
}

\begin{abstract}
Satuan Perangkat Kerja Daerah (SKPD) is a compulsory subject to the Laporan Akuntabilitas Kinerja Instansi Pemerintahan (LAKIP) in Indonesia. Of the many SPKDs incorporated in the city or district governments throughout Indonesia, it was reported that none of them had achieved an A rating of the LAKIP they had compiled. This phenomenon forms the basis for our research to disclose other factors that might influence the assessment of LAKIP on performance appraisal systems for SKPD in Indonesia. Based on research conducted by Spekle and Verbeeten (2013) explained that there is a factor of contractibility that can affect the relationship between the performance appraisal system with the performance used as the dependent variable. Therefore, this study attempts to replicate previous research to test whether it will produce a similar conclusion or not. The type of this research is causal explanatory, where the sample comes from population 3 SKPD located in Bandung while Moderated Regression Analysis (MRA) is used as a data analysis techniquewhether interaction test is a special application of linear regression (multiplication of two or more independent variables).
\end{abstract}

Keywords: Performance Assessment System, Performance, Contractibility, Satuan Perangkat Kerja Daerah (SKPD) Bandung, Public Sector's Performance. 


\section{Pendahuluan}

Instruksi Presiden No.7 Tahun 1999 tentang Akuntabilitas Instansi Pemerintah sebagai dasar lahirnya SAKIP (Sistem Akuntabilitas Kinerja Instansi Pemerintahan) dan LAKIP (Laporan Akuntabilitas Kinerja Instansi Pemerintahan). SAKIP dan LAKIP lahir oleh karena dalam Instruksi Presiden menyebutkan bahwa setiap instansi pemerintah sebagai unsur penyelenggara pemerintahan wajib mempertanggungjawabkan pelaksanaan tugas pokok melalui pelaporan akuntabilitas kinerja instansi pemerintahan.

$$
\text { Pelaksanaan SAKIP dapat }
$$

tercermin dari penyusunan LAKIP, namun SAKIP tidak hanya berbicara mengenai laporan realisasi kinerja serta penjelasan tercapainya atau tidak target yang telah direncanakan, SAKIP pun berbicara mengenai perencanaan, pengukuran, serta pelaporan. Definisi dari SAKIP sendiri sebagaimana tertuang dalam Peraturan Presiden Nomor 29 Tahun 2014 tentang Sistem Akuntabilitas Kinerja Instansi Pemerintah adalah rangkaian sistematik dari berbagai aktivitas, alat dan prosedur yang dirancang untuk tujuan penetapan dan pengukuran, pengumpulan data, pengklarifikasian, pengikhtisaran, dan pelaporan kinerja pada instansi pemerintah, dalam rangka pertanggungjawaban dan peningkatan kinerja instansi pemerintah.

Tujuan SAKIP adalah untuk mendorong terciptanya akuntabilitas kinerja instansi pemerintah sebagai salah satu prasyarat untuk terciptanya pemerintah yang baik dan terpercaya. Sedangkan sasaran dari SAKIP adalah:

1. Menjadikan instansi pemerintah yang akuntabel sehingga dapat beroperasi secara efisien, efektif dan responsif terhadap aspirasi masyarakat dan lingkungannya.

2. Terwujudnya transparansi instansi pemerintah.
3. Terwujudnya partisipasi masyarakat dalam pelaksanaan pembangunan nasional.

4. Terpeliharanya kepercayaan masyarakat kepada pemerintah.

Menurut Asisten III Bidang Administrasi dan Umum Setda Bangka Ahmad Mukhsin pada Hari Kamis 28 Juli 2016 di Gedung Wanita Sungailiat, Bangka pada saat sambutan pelaksanaan Diklat SAKIP dan LAKIP bagi para pegawai PNS, bahwa sudah menjadi suatu tuntutan bagi Satuan Kerja Perangkat Daerah (SKPD) sebagai perangkat kerja pada pemerintah daerah selaku pengguna anggaran/barang untuk melaksanakan SAKIP. Setidaknya terdapat tiga keuntungan yang akan diperoleh pada saat SKPD melaksanakan SAKIP, yaitu kegunaannya dalam mengukur setiap pembangunan atau kinerja yang dilakukan mereka, sebagai tolak ukur untuk mempertanggungjawabkan anggaran yang telah digunakan untuk pembangunan daerah, serta untuk mendorong terciptanya akuntabilitas kinerja instansi pemerintah sebagai salah satu prioritas untuk terciptanya pemerintah yang baik dan terpercaya.

Pada satu sisi, setidaknya terdapat tiga keuntungan yang akan diperoleh bagi SKPD yang melaksanakan SAKIP, namun pada sisi lain Berita CPNS dan Aparatur Sipil Negara mengumumkan bahwa sampai dengan tanggal 31 Maret 2015, penilaian SAKIP untuk kabupaten/kota di Indonesia tidak ada satupun yang bernilai A, hanya 11 kabupaten/kota yang memperoleh nilai $\mathrm{B}$. Terdapat kontradiksi antara keuntungan penerapan SAKIP dengan pencapaian nilai maksimum yang diharapkan. Oleh karenanya pada penelitian ini kami bermaksud untuk mengukur keefektifan sampai sejauh mana SAKIP dapat berkontribusi dalam kinerja yang ditunjukkan oleh PNS SKPD dalam melaksanakan aktivitasnya.

Berdasarkan penelitian yang dilakukan oleh Spekle dan Verbeeten 
(2013) dijelaskan bahwa pengaruh sistem penilaian kinerja berorientasi insentif terhadap kinerja adalah negatif, namun pada saat variabel contractibility yang tinggi memoderasi diantaranya memberikan pengurangan terhadap nilai negatif awal. Kesimpulan yang dihasilkan menyatakan bahwavariabel contractibility dapat memoderasi pengaruh sistem penilaian kinerja berorientasi insentif terhadap kinerja.

Oleh karena itu, penelitian ini diharapkan dapat memberikan jawaban mengapa penilaian SAKIP untuk kabupaten/kota di Indonesia tidak ada yang bernilai A, hipotesis kami berada pada pengaruh variabel mediasi yaitu contractibility.Sehingga penelitian ini bertujuan untuk mengetahui seberapa besar pengaruh sistem penilaian kinerja berorientasi insentif dan eksplorasi terhadap kinerja PNS SKPD di Kota Bandung dengan dan tanpa variabel contracability sebagai variabel moderating.

\section{Kerangka Teoritis dan Hipotesis}

\section{Teori Motivasi}

Motivasi merupakan proses yang menentukan intensitas, arah, dan ketekunan individu dalam usaha mencapai sasaran (Robbins, 2006). Sedangkan kinerja merupakansuatu fungsi dari motivasi dan kemampuan (Wono \& Achmadi, 2008).Dengan demikian melalui motivasi tertentu dapat menghasilkan tindakan berupa kinerja dari seseorang.

Setiap individu pada dasarnya memiliki tingkatan kebutuhan yang berbeda-beda, dari tingkatan terendah menurut Maslow yaitu kebutuhan fisiologis yang merupakan kebutuhan untuk bertahan hidup secara fisik hingga tingkatan tertinggi yaitu kebutuhan aktualisasi diri yang merupakan kebutuhan untuk memenuhi potensi dirinya. Motivasi berperan penting dalam mencapai pemenuhan tingkatan kebutuhan individu. Motivasi berperan sebagai pendorong individu untuk melakukan suatu aksi dan tindakan nyata yang berwujud pada kinerja dari individu tersebut. Menurut August W. Smith, "performance isoutput derives from processes, human otherwise", artinya kinerja merupakan hasil dari suatu proses yangdilakukan oleh manusia. Untuk dapat menyelesaikan tugasnya, seseorang harus memiliki suatu keahlian maupunketerampilan tertentu.Organisasi seringkali menilai keterampilan dan kemampuan seseorang dalam mencapai kinerjanya melalui penilaian kinerja.

\section{Penilaian Kinerja}

Penilaian kinerja merupakan salah satu alat manajemen untuk membentuk motivasi, persaingan positif/kompetisi pekerja untuk mencapai nilai maksimal yang bisa dilakukan untuk mendapatkan nilai atau pengakuan atas prestasinya. Pengakuan tersebut bisa berbentuk sistem kenaikan gaji, kenaikan jabatan, fasilitas, bonus dan banyak bentuk penghargaan pada pekerja (Rivai dan Basri, 2004).

Menurut Dessler (2000) terdapat tiga faktor penting yang seringkali digunakan dalam penilaian kinerja, yaitu:

1. Prestasi kerja yang meliputi keakuratan, ketelitian, keterampilan, dan penerimaan keluaran.

2. Kuantitas pekerjaan

3. Kepemimpinan yang meliputi pemberian saran, arahan atau perbaikan.

Penilaian kinerja pada instansi pemerintah yang mana pelaksanaan programnyamenggunakan anggaran APBN/APBD dilakukan berdasarkan SAKIP LAKIP yang menggambarkan kinerja yang dicapai oleh suatu instansi pemerintahan. SAKIP merupakan Sistem Akuntabilitas Kinerja Instansi Pemerintahan yang menggambarkan sistem yang terpadu dari perencanaan, penganggaran, dan pelaporan kinerja 
instansi.Sedangkan LAKIP merupakan hasil akhir dari SAKIP yang menunjukan pencapaian kinerja instansi pemerintah.

\section{Akuntabilitas Kinerja}

SAKIP LAKIP ditetapkan berdasarkan Inpres No.7 Tahun 1999 tentang Akuntabilitas Instansi Pemerintah.Melalui Inpres tentang Akuntabilitas Instansi Pemerintah tersebut instansi pemerintah berkewajiban mempertanggungjawabkan pelaksanaan program kerjanya. Akuntabilitas kinerja merupakan kewajiban untuk menjawab dari perorangan, badan hukum ataupun pimpinan kolektif secara transparan mengenai keberhasilan atau kegagalan dalam melaksanakan misi organisasi kepada pihak yang berwenang menerima pelaporan akuntabilitas atau pemberi amanah (LKIP, 2015).

Sedangkan Akuntabilitas Kinerja Instansi Pemerintah merupakan perwujudan kewajiban suatu instansi pemerintah untuk mempertanggung jawabkan keberhasilan atau kegagalan pelaksanaan visi dan misi organisasi dalam mencapai tujuan dan sasaran yang telah ditetapkan melalui alat pertanggung jawaban secara periodik (LAKIP, 2014).

Berdasarkan

Laporan

Akuntabilitas Kinerja Instansi Pemerintah (2014), evaluasi bertujuan agar diketahui pencapaian realisasi, kemajuan dan kendala yang dijumpai dalam rangka pencapaian misi, agar dapat dinilai dan dipelajari guna perbaikan pelaksanaan program/kegiatan di masa yang akan datang. Selain itu, dalam evaluasi kinerja dilakukan pula analisis efisiensi dengan cara membandingkan antara output dengan input baik untuk rencana maupun realisasi. Analisis ini menggambarkan tingkat efisiensi yang dilakukan oleh instansi dengan memberikan data nilai output per unit yang dihasilkan oleh suatu input tertentu. Selanjutnya dilakukan pula pengukuran/penentuan tingkat efektivitas yang menggambarkan tingkat kesesuaian antara tujuan dengan hasil, manfaat atau dampak. Selain itu, evaluasi juga dilakukan terhadap setiap perbedaan kinerja (performance gap) yang terjadi, baik terhadap penyebab terjadinya gap maupun strategi pemecahan masalah yang telah dan akan dilaksanakan.

$$
\text { Dalam melakukan evaluasi }
$$

kinerja, perlu juga digunakan pembandingan pembandingan antara:

1. Kinerja nyata dengan kinerja yang direncanakan.

2. Kinerja nyata dengan kinerja tahuntahun sebelumnya.

3. Kinerja suatu instansi dengan kinerja instansi lain yang unggul di bidangnya ataupun dengan kinerja sektor swasta.

4. Kinerja nyata dengan kinerja di negaranegara lain atau dengan standar Internasional

\section{Penggunaan Sistem Pengukuran Kinerja}

Penggunaan sistem pengkuran kinerja di sektor publik bertujuan untuk membantu manajer publik dalam menilai pencapaian strategi yang telah ditetapkan.Terdapat 16 sistem pengukuran kinerja yang berbeda di setiap organisasi. Kelompok peran sistem ini dibagi menjadi lima kategori besar yaitu (1) mengukur kinerja, termasuk kemajuan monitoring, mengukur dan mengevaluasi kinerja; (2) strategy management, yang meliputi perencanaan, strategi formulasi / pelaksanaan / eksekusi, perhatian fokus, dan keselarasan; (3) internal dan eksternal komunikasi, benchmarking, dan sesuai dengan peraturan; (4) mempengaruhi perilaku, yang terdiri perilaku bermanfaat, mengelola hubungan, dan kontrol; dan (5) pembelajaran dan peningkatan, menangkap umpan balik (feedback), dan peningkatan kinerja (Franco-Santos et al., 2007 dalam Speklé dan Verbeeten 2013).

Keberhasilan dalam pencapaian hasil kerja maupun peningkatan kinerja tidak terlepas dari motivasi kerja yang mendasari seseorang untuk bertindak.Hasil penelitian terdahulu yang menguji pengaruh motivasi terhadap kinerja maupun peningkatan kinerja menunjukkan bahwa 
terdapat pengaruh yang signifikan antara motivasi kerja dengan kinerja (Agustin (2012), Bestari (2011), Mahardhika dkk (2013), Nitasari (2012)).Dengan demikian dapat dikatakan bahwa seseorang membutuhkan dorongan untuk dapat melakukan suatu pekerjaan dan mencapai suatu hasil kerja, yang mana dorongan tersebut merupakan motivasi kerja.

\section{Motivasi Kerja}

Motivasi kerja yang paling umum yang terdapat dalam diri seorang pekerja adalah kompensasi dan pengharapan (Hughes et al dalam Koesmono, 2005). Kompensasi merupakan imbal jasa yang diberikan atas kontribusi kerja, sedangkan pengharapan merupakan harapan-harapan dari pekerja untuk dapat maju dalam pekerjaannya.

Orientasi insentif digunakan untuk memeriksa dampak dari New Public Management dengan menggunakan sistem pengukuran kinerja (Newberry dan Pallot, 2004 dalam Speklé dan Verbeeten 2013).Dalam penelitian terdahulu faktor insentif seringkali muncul sebagai faktor yang paling menonjol yang memotivasi kerja seseorang disamping faktor penguat positif.

Hasil penelitian Mahardhika dkk (2013) menjelaskan bahwa hal yang paling mendasar dalam mengindikasikan motivasi positif adalah pemberian imbalan berupa insentif gaji.Artinya bagaimanapun kondisi suasana kerja sangat baik, namun faktor pendapatan memegang peranan paling mendasar.Hal ini sesuai dengan teori kebutuhan Maslow yang menjelaskan pemenuhan kebutuhan yang paling mendasar adalah kebutuhan fisiologis.

\section{Contractibility}

Menurut Speklé dan Verbeeten (2013), cara di mana sistem pengukuran kinerja di sektor publik digunakan mempengaruhi kinerja organisasi, dan bahwa efek kinerja ini tergantung pada contractibility. Contractibility meliputi kejelasan tujuan, kemampuan untuk memilih ukuran kinerja yang tidak mengalami distorsi, dan sejauh mana manajer tahu dan mengontrol proses perubahan. Kebanyakan organisasi sektor publik yang menggunakan sistem pengukuran kinerja dengan cara yang sesuai dengan karakteristik kegiatan mereka. Berdasarkan penelitian Speklé dan Verbeeten (2013) menunjukkan bahwa contractibility memoderasi hubungan antara penggunaan sistem pengukuran kinerja berorientasi insentif dengan kinerja.Penggunaan sistem pengukuran kinerja untuk tujuan insentif berpengaruh secara negative terhadap kinerja organisasi, tetapi efek ini menjadi ringan ketika contractibility tinggi.

\section{Metode Penelitian}

\section{Populasi dan Sampel}

Populasi adalah wilayah generalisasi yang terdiri atas objek atau subjek yang mempunyai kualitas dan karakterisktik tertentu yang ditetapkan oleh peneliti untuk dipelajari dan kemudian ditarik kesimpulan (Sugiyono, 2011:117). Populasi adalah keseluruhan objek yang karakteristiknya akan diuji (Suliyanto, 2006). Populasi dalam penelitian ini adalah seluruh PNS (pegawai negeri sipil) yang bekerja pada satuan perangkat daerah Kota Bandung. Oleh karena objek penelitian pada penelitian ini adalah Asisten Administrasi Umum dan Kepegawaian, Asisten Pemerintahan dan Kesra, dan Asisten Perekonomian dan Pembangunan Kota Bandung yang berkantor di Jalan Wastukencana No.2 Bandung, maka populasi akan mencakup seluruh PNS yang bekerja pada bagian tersebut.

Sampel adalah bagian dari jumlah dan karakteristik yang dimiliki oleh populasi tersebut (Sugiyono, 2011:118).Sampel yang baik adalah sampel yang benar-benar dapat digunakan untuk menggambarkan karakteristik populasinya (Suliyanto, 2006). Teknik pengambilan sampel yang digunakan adalah random 
sampling dimana setiap unit dalam populasi mempunyai kesempatan yang sama untuk dipilih menjadi anggota sampel.

\section{Teknik Pengujian Data dengan MRA}

Variabel moderating adalah variabel independen yang berfungsi menguatkan atau melemahkan hubungan antara variabel independen terhadap variabel dependen. Ada beberapa cara untuk menguji regresi dengan variabel moderating dan salah satunya adalah Moderated Regression Analysis (MRA). Moderated Regression Analysis (MRA) atau uji interaksi merupakan aplikasi khusus regresi berganda linear dimana dalam persamaan regresinya mengandung unsur interaksi (perkalian dua atau lebih variabel independen) (Liana Lie, 2009).

\section{Hasil Penelitian dan Pembahasan}

Tabel 1

ANOVA tanpa Variabel Contractability

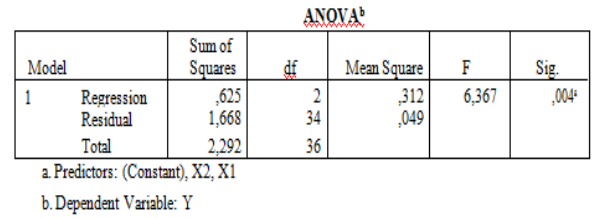

Tabel 2

Model Summary tanpa Contractability

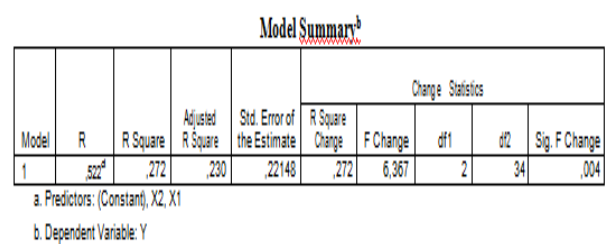

Tabel 3

\section{Coefficient tanpa Contractability}

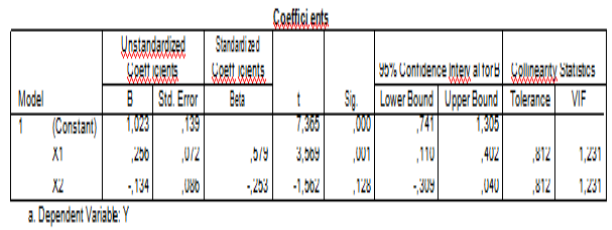

Tabel 4

ANOVA dengan Contractability

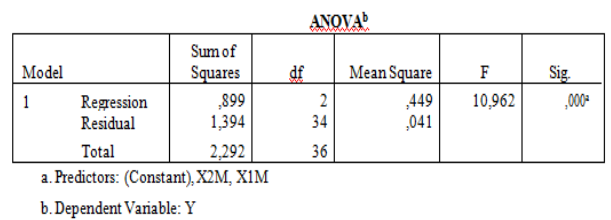

Tabel 5

Model Summary dengan Contractability

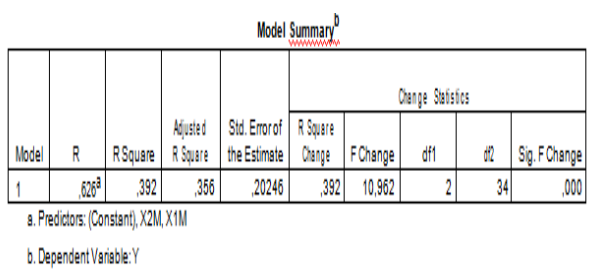

Tabel 6

Coefficient dengan Contractability

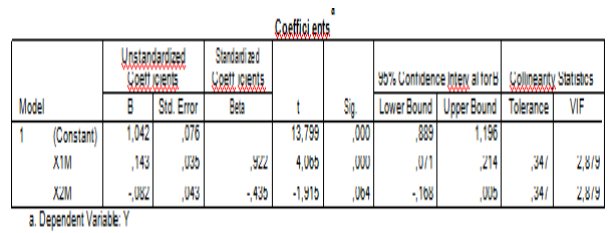

Setelah melakukan pengolahan data dengan menggunakan SPSS versi 13, diperoleh hasil bahwa dengan maupun tanpa contracability sebagai variabel moderating, hasil dari Tabel 1 dan Tabel 4 diperoleh nilai significance $\mathrm{F}$ sebesar 0,004 dan 0,000 yang berada di bawah nilai $Z \alpha$ sebesar 0.05 , yang berarti bahwa 
$\mathrm{H}_{0}$ ditolak dan $\mathrm{H}_{1}$ diterima. Dengan demikian sistem penilaian kinerja berorientasi insentif berpengaruh secara positif dan eksplorasi berpengaruh secara negatif signifikan terhadap kinerja PNS SKPD di Kota Bandung. Adapun besarnya pengaruh ditunjukkan dari nilai R-square pada Tabel 2 dan Tabel 5, yaitu sebesar $27,2 \%$ tanpa contractability sebagai variabel moderating dan sebesar $39,2 \%$ dengan contractability sebagai variabel moderating.

\section{Simpulan dan Saran}

Berdasarkan hasil penelitian diatas, maka diperoleh kesimpulan sebagai berikut:

1. Sistem penilaian kinerja berorientasi insentif berpengaruh secara positif signifikan terhadap kinerja PNS SKPD di Kota Bandung. Artinya semakin tinggi sistem penilaian kinerja berorientasi insentif, maka akan meningkatkan kinerja PNS SKPD di Kota Bandung.

2. Sistem penilaian kinerja berorientasi eksplorasi berpengaruh secara negatif signifikan terhadap kinerja PNS SKPD di Kota Bandung. Artinya semakin tinggi sistem penilaian kinerja berorientasi eksplorasi, maka akan menurunkan kinerja PNS SKPD di Kota Bandung.

3. Sistem penilaian kinerja berorientasi insentif berpengaruh secara positif signifikan terhadap kinerja PNS SKPD di Kota Bandung dengan contractability sebagai variabel moderating. Artinya semakin tinggi sistem penilaian kinerja berorientasi insentif yang diperkuat dengan contractability akan meningkatkan kinerja PNS SKPD di Kota Bandung.

4. Sistem penilaian kinerja berorientasi eksplorasi berpengaruh secara negatif signifikan terhadap kinerja PNS SKPD di Kota Bandung dengan contractability sebagai variabel moderating. Artinya semakin tinggi sistem penilaian kinerja berorientasi eksplorasi yang diperkuat dengan contractability akan menurunkan kinerja PNS SKPD di Kota Bandung.

\section{Daftar Pustaka}

Agustin, Fidya, W; 2012.Pengaruh Motivasi Kerja Terhadap Prestasi Kerja pada PT. Hero Sakti Motor Gemilang Malang Jawa Timur. Skripsi Fakultas Ilmu Administrasi Universitas Brawijaya.

Agustina, Vina dan Yoestini. 2012. Analisis Pengaruh Kualitas Pelayanan, KepuasanPelanggan, dan Nilai Pelanggan dalam Meningkatkan Loyalitas Pelanggan Joglosemar Bus. Diponegoro Journal of Management., Vol 1, No.1, hal. 111.

Bestari, Muhammad, P; 2011.Pengaruh Motivasi dan Disiplin Kerja Terhadap PrestasiKerja pada PT. Indosat, Tbk Cabang Malang.Skripsi Fakultas Ilmu AdministrasiBisnis Universitas Brawijaya Malang.

Hartono. 2011. Metodologi Penelitian. Zanafa Publishing. Pekanbaru.

Lie Liana. 2009. Penggunaan MRA dengan SPSS untuk Menguji Pengaruh VariabelModerating terhadap Hubungan antara Variabel Independen dan Variabel Dependen.Jurnal Teknologi Informasi DINAMIK Vol.2.Juli 2009.pp.90-97.

Priyanto, Dwi. 2008. Mandiri Belajar SPSS.Mediakom. Yogyakarta.

Rangga Mahardhika, Djamhur H., dan Ika R., 2013. Pengaruh Motivasi Kerja TerhadapKinerja Karyawan (Survey Pada PT AXA Financial Indonesia Sales Office 
Jurnal Akuntansi Maranathan Volume 10 Nomor 2, November 2018 : 223-230

\section{Malang).Universitas Brawijaya}

Malang.

Rivai V dan Ahmad F. M. B., 2005.Performance Appraisal,

Raja Grafindo Semesta, Jakarta.

Robbins S.P., 2006, Organizational Behavior, Prentice Hall International.INC, USA.

Sarbini Wono dan Surachman F.A., 2008.Pengaruh Sistem Penilaian Kinerja danKeterbukaan Nilai Kerja Terhadap Motivasi Kerja (Kasus Pekerja Bottom Line di Perusahaan Rokok PT.G). Jurnal Manajemen dan Kewirausahaan Vo.10 No.1, 2008pp: 18-29.

Spekle, Roland F. and Frank H.M. Verbeeten. 2014. The Use of Performance MeasurementSystems in The Public Sector: Effects on Performance. Management AccountingResearch. Volume 12, Issue 2, June 2014, Pages 131-146.

Sugiyono. 2011. Metode Penelitian Pendidikan. Alfabeta. Bandung.

Suliyanto. 2006. Metode Riset Bisnis. Penerbit Andi. Yogyakarta.

Sunjoyo, dkk.2013. Aplikasi SPP Untuk Smart Riset.Alfabeta. Bandung. 